\title{
First record in Belgium of Trissolcus basalis (Hymenoptera, Scelionidae), an egg parasitoid of economically important stink bugs (Hemiptera, Pentatomidae)
}

\author{
Olivier Hendrik Berteloot ${ }^{1, *}$, Lore Vervaet ${ }^{1}$, Huayan Chen ${ }^{2,3}$, \\ Elijah J. Talamas ${ }^{4}$, Thomas Van Leeuwen ${ }^{1} \&$ Patrick De Clercq ${ }^{1}$ \\ ${ }^{1}$ Department of Plants and Crops, Faculty of Bioscience Engineering, Ghent University (UGent), \\ Coupure Links 653, Ghent, Belgium. \\ ${ }^{2}$ State Key Laboratory of Biocontrol, School of Life Sciences, Sun Yat-sen University, \\ Guangzhou, China. \\ ${ }^{3}$ Department of Entomology, The Ohio State University, Colombus, OH, U.S.A. \\ ${ }^{4}$ Florida Department of Agriculture and Consumer Services, Gainesville, FL., U.S.A. \\ ${ }^{*}$ Corresponding author: Olivier.Berteloot@UGent.be
}

\begin{abstract}
The scelionid parasitoid Trissolcus basalis (Wollaston,1858) has been detected in Belgium for the first time based on specimens reared from a parasitized egg mass of Nezara viridula (Linnaeus,1758) collected in an urban garden at Sint-Amandsberg, Ghent. Identification was based on adult morphology and DNA barcoding. This is presently believed to be the northernmost record in Europe of T. basalis and could be the consequence of a northward expansion of this species due to climate change. This first record may be of economic importance for the biological control of stink bug pests in Belgian vegetable and fruit production.
\end{abstract}

Keywords. Stink bug, egg parasitoid, Scelionidae, Trissolcus basalis, DNA barcoding.

Berteloot O.H., Vervaet L., Chen H., Talamas E.J., Van Leeuwen T. \& De ClercQ P. (2021). First record in Belgium of Trissolcus basalis (Hymenoptera, Scelionidae), an egg parasitoid of economically important stink bugs (Hemiptera, Pentatomidae). Belgian Journal of Zoology 151: 139-148. https://doi.org/10.26496/bjz.2021.90

\section{Introduction}

Parasitoid wasps in the family Scelionidae (Hymenoptera: Platygastroidea) are gaining increasing attention for biological control due to their parasitism of eggs of key insect pests in agriculture. Trissolcus basalis (Wollaston, 1858) (Hymenoptera: Scelionidae) belongs to the basalis-species group of the genus Trissolcus (sensu JOHNSON 1987; TALAMAS et al. 2017) and is a solitary egg parasitoid of stink bugs with an assumed worldwide distribution (COLAZZA \& BIN 1995). The taxonomy of the superfamily Platygastroidea was recently revised, reaffirming the Scelionidae as a valid family (CHEN et al. 2021).

Trissolcus basalis is a generalist and is known to parasitize the eggs of a wide range of pentatomid hosts (JONES 1988). However, the most common host is the southern green stinkbug Nezara viridula 
(Linnaeus, 1758) (Hemiptera: Pentatomidae) (COLAZZA et al. 1995; MCPHERSON \& MCPHERSON 2000). Due to increased global transportation and climate change, non-native species can establish populations beyond their natural distribution (ZISKA et al. 2011). When non-native herbivores such as $N$. viridula invade cropping systems, they can quickly become serious pests. Nezara viridula is a highly polyphagous herbivore and due to its habitat expansion, it has become one of the most economically important species of Hemiptera causing damage to crops in the open field and greenhouses (PANIZZI 2000; MCPHERSON \& MCPHERSON 2000). Its geographic origin is uncertain but is assumed to be eastern Africa or the Mediterranean (HOKKANEN 1986). Within the last decade, established breeding populations were documented throughout eastern and western Europe, including Belgium (SCHMITZ 1986; PANIZZI 2000; RÉDEI \& TORMA 2003; BARClAY et al. 2004; WERNER 2005; MuSOlIn 2012; DETHIER \& CHÉROT 2014; AuKema 2016; Grozea et al. 2016; RABitsch 2016: HeMAla \& KMENT 2017).

Trissolcus basalis has recently also been recorded parasitizing eggs of the brown marmorated stinkbug, Halyomorpha halys (Stål, 1855), in the United States (BALUSU et al. 2019; TILlman et al. 2020). Trissolcus basalis has also been reported to have emerged from $H$. halys eggs in Italy (RONDONI et al. 2017). Halyomorpha halys is native to eastern Asia and has gained pest status in orchards and vegetable crops in most of the U.S.A., as well as in southern and western Europe (HOEBEKE \& CARTER 2003; WeRMELINGER et al. 2008; FOGAIN \& GRAFF 2011; LESKEY et al. 2012; LEE et al. 2013; RiCE et al. 2014; HAYE et al. 2015; BARISELLI et al. 2016). In Belgium, H. halys has been detected since 2017 and is assumed to have established overwintering breeding populations (CLAEREBAUT et al. 2019). A first report from Haspengouw in July 2021 indicates that $H$. halys is already present in commercial pipfruit orchards in Belgium, but currently no damage has been reported (G. Peusens, pers. comm. 27 July 2021).

Established or augmented populations of egg parasitoids like T. basalis may assist in the biological control of stink bug pests, $N$. viridula in particular, and help relieve the imminent threat posed by H. halys on crop production in Belgium and other European countries (CANTÓN-RAMOS \& CALLEJONFERRE 2010; KOCH et al. 2017).

\section{Material and methods}

A single mass of $73 \mathrm{~N}$. viridula eggs was collected from a Stevia rebaudiana leaf (Asteraceae) on 28 August 2020 in an urban garden at Sint-Amandsberg (Ghent), Belgium (51 ${ }^{\circ} 3^{\prime} 20.666^{\prime \prime}$ N, $3^{\circ} 44^{\prime} 53.297^{\prime \prime}$ E). The egg mass was placed in a climatic chamber in the laboratories of the Department of Plants and Crops, Ghent University, set at $24^{\circ} \mathrm{C}, 18: 6 \mathrm{~h} \mathrm{~L}$ :D and 70\% RH (PHCBI MLR-352H-PE, Japan) and held for emergence of stink bug nymphs or adult parasitoids. Over 50 parasitoid adult wasps emerged from this egg mass with a sex ratio of 1:9 male to female.

A culture was started from a single isolated mated female wasp from the field-collected egg mass and kept at the above-mentioned climatic conditions by offering fresh $(<24 \mathrm{~h}$ old $) N$. viridula egg masses, from a culture maintained at the Department of Plants and Crops, Ghent University. The culture of the parasitoid was kept in polystyrene insect breeding dishes $(100 \times 40 \mathrm{~mm}$; SPL Life Sciences Co., Korea). The adults of the F1 generation and all subsequent generations were fed with a drop of honey placed directly on the breeding dish. Water was provided via moistened synthetic cotton (Roltasoft Hartmann, Germany).

The parental specimen and four F1 specimens were morphologically identified using the key of TALAMAS et al. (2017). Specimens were deposited at the Ghent University Museum, Zoology Collections with collection numbers: UGMD_104422 and UGMD_104423. 
Furthermore, twenty frozen adult individuals of both sexes from the F2 generation, originating from a single mated female were pooled for DNA extraction and mitochondrial cytochrome c oxidase I (COI) fragment sequencing. DNA was extracted using a DNeasy Blood and Tissue Kit (Qiagen). The DNA samples were quantified using a NanoDrop2000 spectrophotometer (Thermo Scientific). At least 20 ng of genomic DNA was used per PCR. The 5'-COI region was PCR-amplified using the primers [LCO1490 (5'-GGT CAA CAA ATC ATA AAG ATA TTG G-3') and HCO-2198 (5'-TAA ACT TCA GGG TGA CCA AAA AAT CA-3') (FOLMER et al. 1994). The PCR was performed in a $50 \mu 1$ reaction volume: $1 \mu \mathrm{l}$ DNA, $29.5 \mu 1$ molecular grade water, $10 \mu 1$ XX Green GoTaq Flexi PCR buffer, $2.5 \mu 1$ dNTPs ( $25 \mathrm{mM}$ each), $5 \mu 1 \mathrm{MgCl}_{2}, 1.5 \mu 1$ of each primer ( $1 \mu \mathrm{M}$ each), $0.2 \mu \mathrm{l}$ GoTaq G2 Flexi DNA polymerase $(5 \mathrm{u} / \mu \mathrm{l})$ (Promega Corp.,Wisconsin, USA). Thermocycling conditions were optimized to shorten reaction times and included initial denaturation at $94{ }^{\circ} \mathrm{C}$ for $300 \mathrm{~s}$, followed by 35 cycles of $94{ }^{\circ} \mathrm{C}$ for $30 \mathrm{~s}$, annealing at $41^{\circ} \mathrm{C}$ for $45 \mathrm{~s}$ and extension at $72^{\circ} \mathrm{C}$ for $60 \mathrm{~s}$; then further $600 \mathrm{~s}$ at $72^{\circ} \mathrm{C}$ for

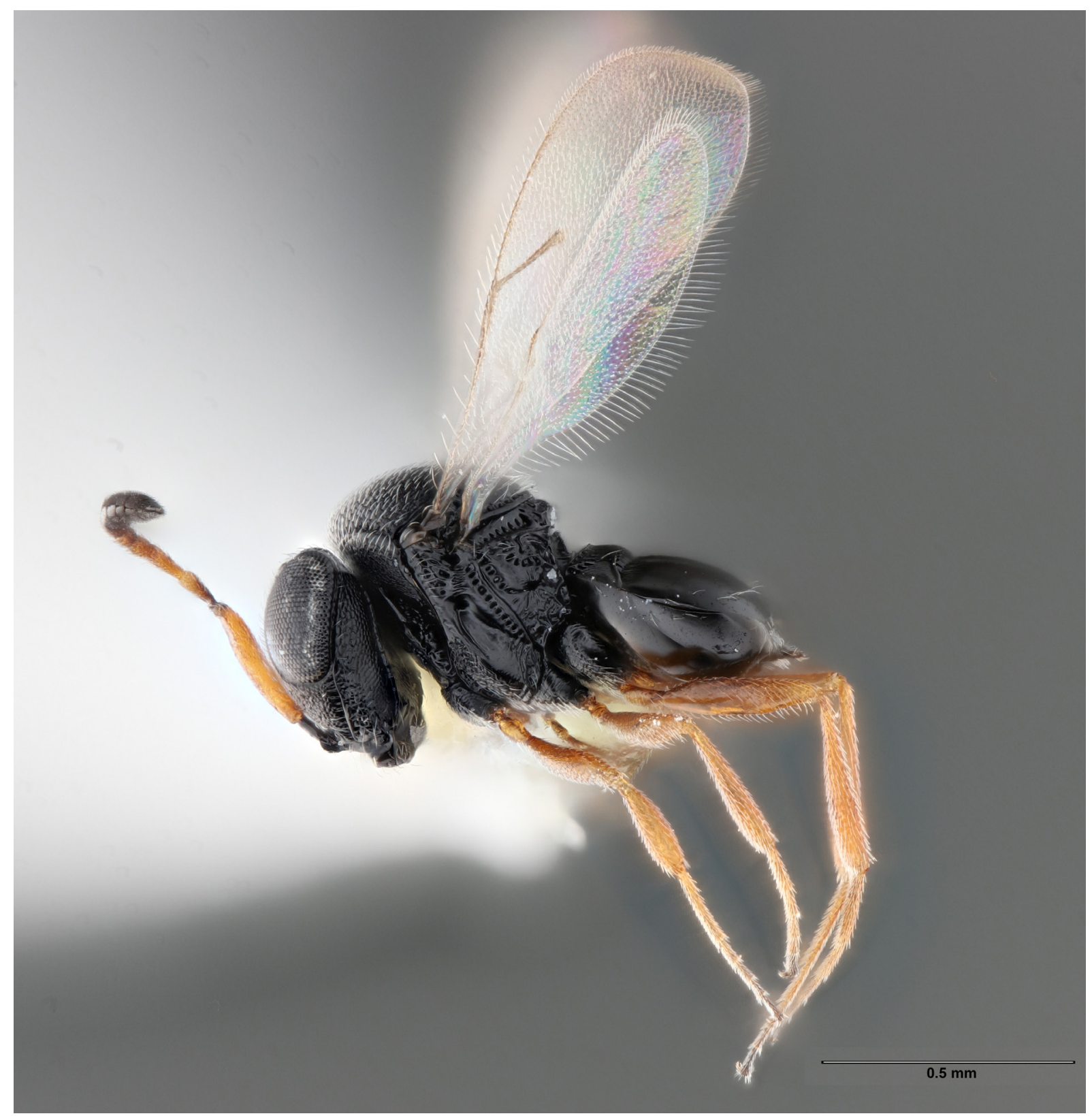

Figure 1 - Lateral habitus of Trissolcus basalis (female) collected near Ghent, Belgium. 


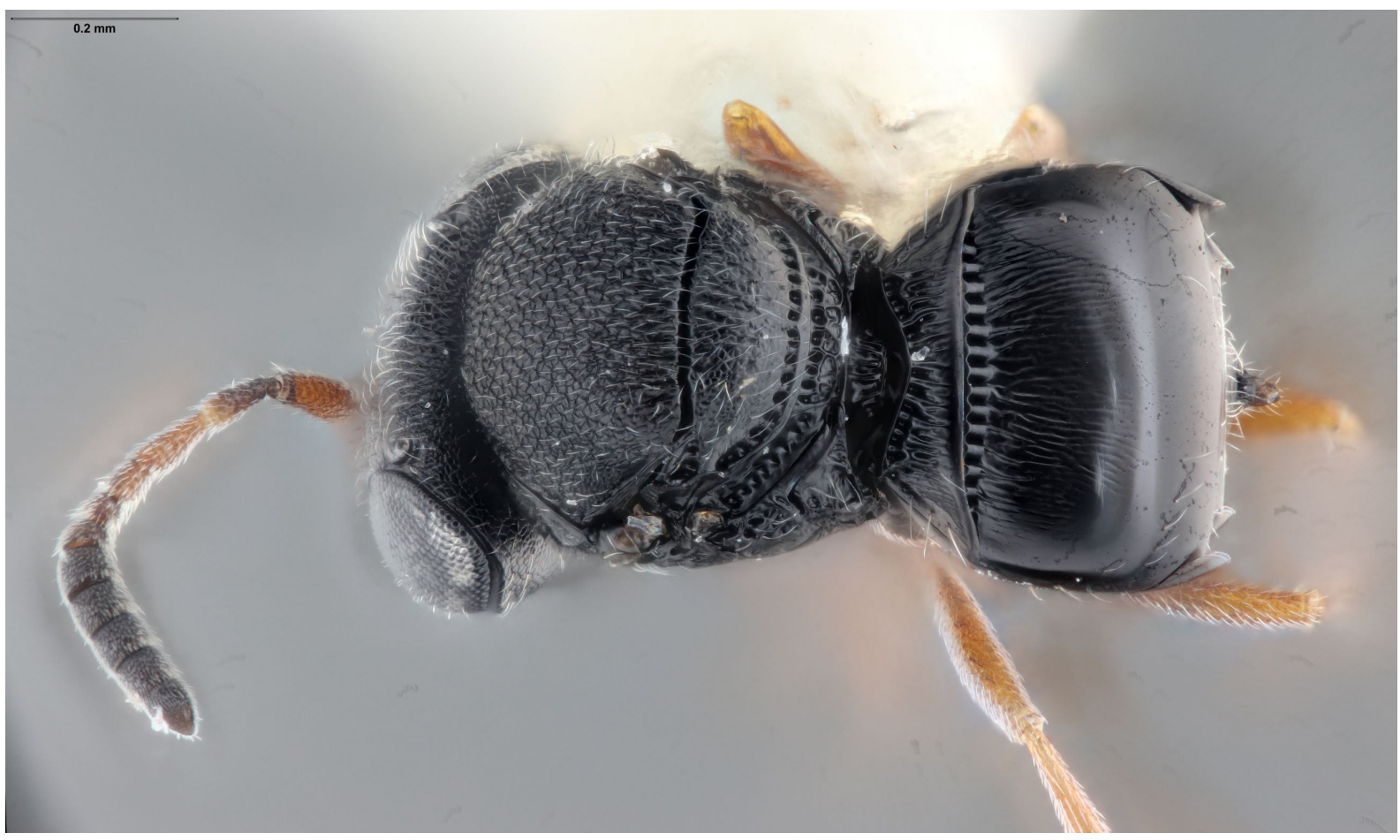

Figure 2 - Dorsal habitus of Trissolcus basalis (female).

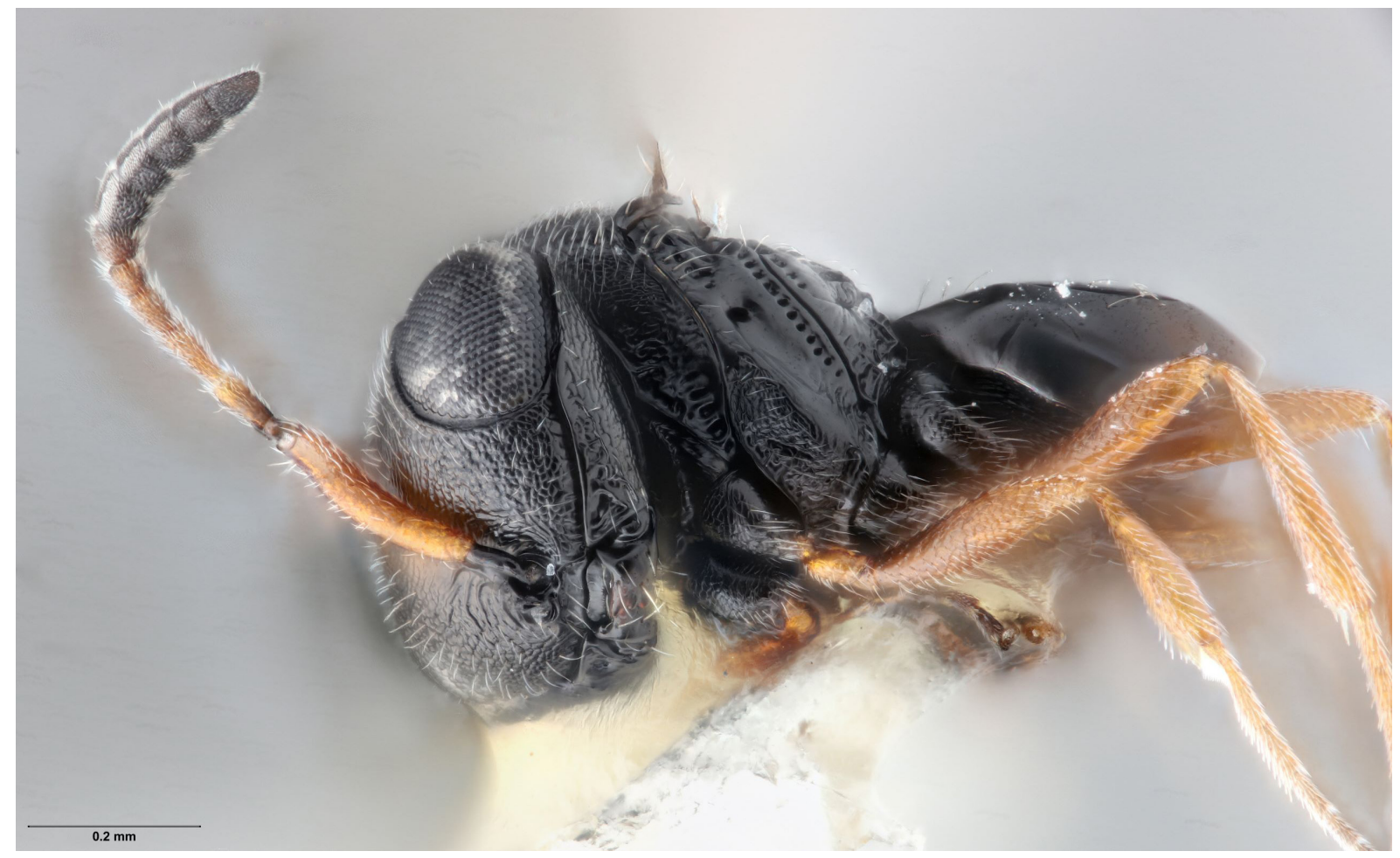

Figure 3 - Ventrolateral habitus of Trissolcus basalis (female). 
final extension. All PCR products were purified using the E.Z.N.A Cycle Pure Kit (Omega Bio-tek Inc, Georgia, USA) following the manufacturer's instructions and sent for sequencing to an external service (LGC Genomics GmbH, Berlin, Germany). The obtained forward and reverse sequences were inspected and a consensus sequence was made using the BioEdit Software ver. 7.2.0. The consensus sequence was compared with sequences present in the GenBank database by similarity search using the Basic Local Alignment Search Tool (http://ncbi.nlm.nih.gov/BLASTn), to confirm the taxonomic identity. The COI sequence generated was deposited in GenBank (MZ087751).

We checked collections at the Royal Belgian Institute of Natural Sciences, The Entomological Conservatory at Gembloux and online databases including fauna-eu.org (DE JONG et al. 2014) (accessed 20 October 2021) and gbif.org (GBIF, accessed 20 October 2021) to confirm that our record is in fact the first record in Belgium.

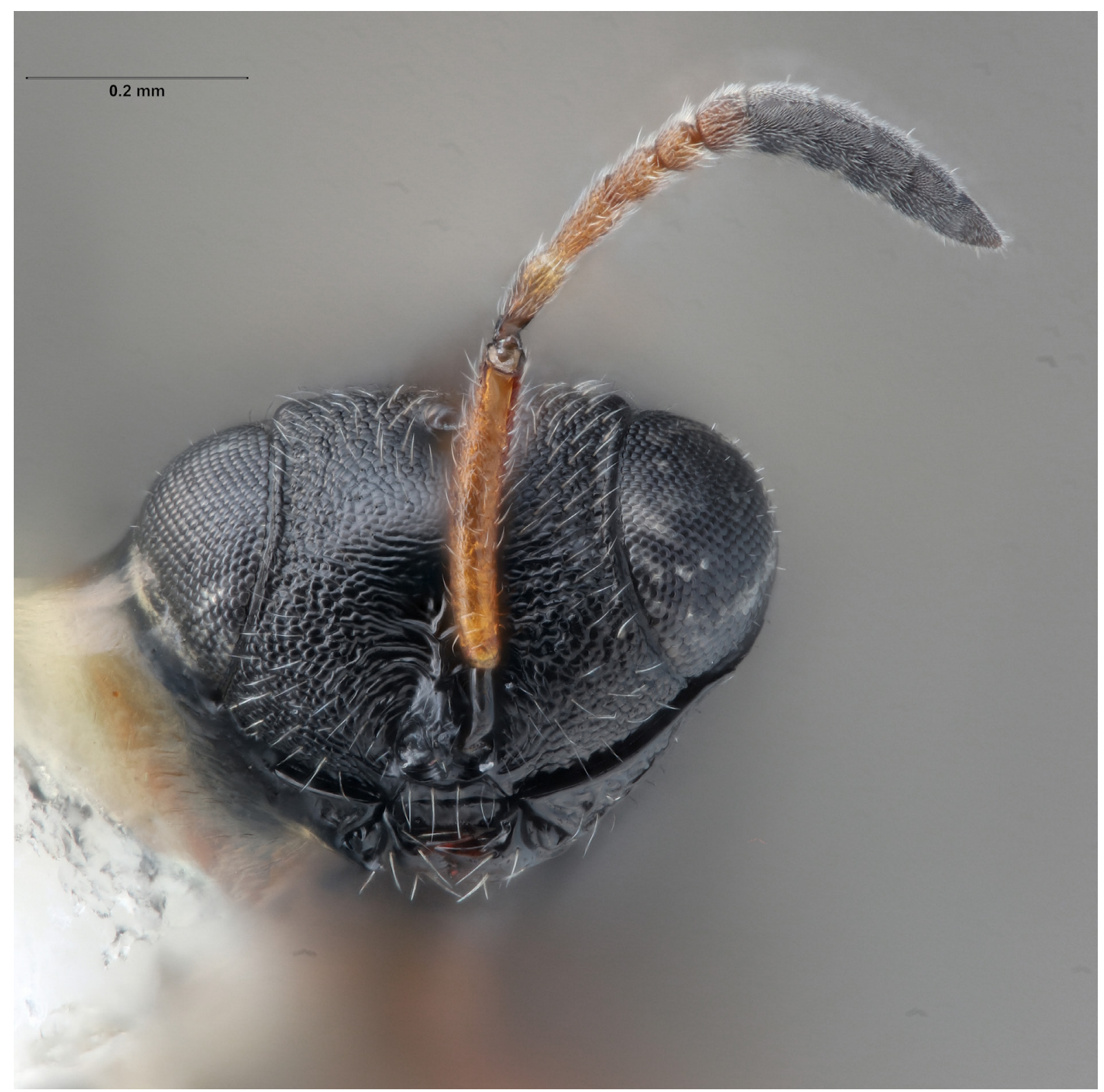

Figure 4 - Anterior head of Trissolcus basalis (female). 


\section{Results}

Both the morphological and molecular identifications with barcoding converged to the same species: Trissolcus basalis. The BLASTn query returned over 10 sequences of T. basalis with a percent identity of $100 \%$ and E-values of 0.0 , therefore showing high similarity with other T. basalis sequences. According to TALAMAS et al. (2017), T. basalis can be identified by the combination of the following characters: vertex without hyperoccipital carina, netrion sulcus incomplete, mesopleuron with episternal foveae shallowly impressed, metapleuron without setation and without well-defined paracoxal sulcus, mesoscutal humeral sulcus present as a smooth furrow and second metasomal tergite with longitudinal striation (Figs 1-4).

\section{Discussion}

The parasitized egg mass collected at Sint-Amandsberg (Ghent) represents the first record of T. basalis in Belgium and indicates the presence of an established breeding population. There have been no commercial releases of this species for biological control nor any known laboratory cultures in the area, excluding introduction from these sources.

Although T. basalis is considered to be globally distributed (JONES 1988; COLAZZA 1995; TALAMAS 2017), its distribution within Europe has been rather sparsely documented, with records from Cyprus, Montenegro, Portugal, Spain, Italy, Hungary, France and Germany (AwAN et al. 1990; ColAZZA 1995; TORTORICI et al. 2019; AWAD et al. 2021). These European specimens were collected in more southern countries or regions. Records from France were from the Aquitaine and Provence-Alpes-Côte-d'Azur, two southern regions (USMENT00896070-00896071, 00896037-00896040, 00896055-0089604060, and 0089629, examined by TALAMAS et al. (2017)). The specimens from Germany (SMNS_Hym_ Sce_000805-000806, examined in AWAD et al. (2021)) were collected in the most southern state, BadenWürttemberg. Our record from Belgium would therefore constitute the northernmost record of T. basalis at present in Europe. It is possible that only in recent decades, T. basalis has colonized Belgium and other parts of northwestern Europe or has become ubiquitous enough to be detected in this area due to the northward habitat expansion of its prime host $N$. viridula. Additionally, the warming of the climate in northwestern Europe could have played a role in the gradual northward habitat expansion of T. basalis following its main host $N$. viridula.

In order to aid further research on the distribution of this parasitoid wasp in Europe, we have mapped all European records (Fig. 5).

More extensive studies on egg parasitoids of Pentatomidae in Belgium and Western Europe will greatly increase our knowledge of biological control of the various stink bug species currently causing economic damage in the area.

Given the economic importance of some of their pentatomid hosts, it will likely be beneficial to support or attract these parasitic wasps to agricultural fields and commercial fruit orchards in a conservation biological control approach (RAHAT et al. 2005). In this context, it may be warranted to further investigate the physical and chemical cues by which these parasitoid wasps locate and recognize their hosts (BIN et al. 1993; MATTIACCI et al. 1993) or plant resources (MARTORANA et al. 2017). Moreover, the interactions between populations of $T$. basalis and other species of egg parasitoids deserve attention. This knowledge will be instrumental in designing lntegrated Pest Management (IPM) strategies against stink bug pests in Belgium and its neighbouring countries. 


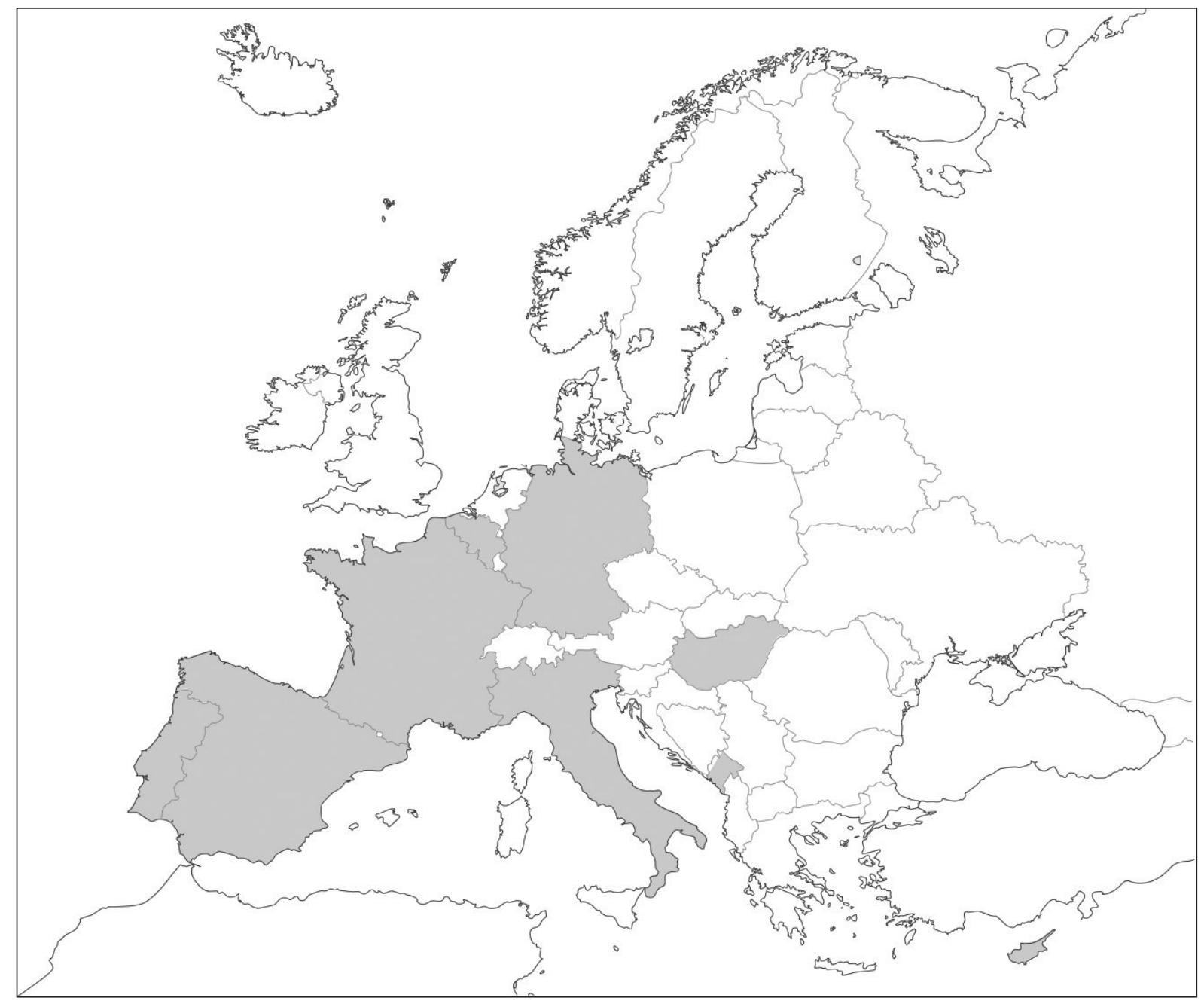

Figure 5 - Map of Europe with highlighted countries where T. basalis was recorded (according to TALAMAS et al. 2017; TORTORICI et al. 2019 and AWAD et al. 2021).

\section{Acknowledgements}

This research was in part supported by funds from VLAIO (Flanders Innovation and Entrepreneurship) through LA-traject HBC.2018.2224 ("SOS Penta").

\section{References}

Aukema B. (2016). Nieuwe en interessante Nederlandse wantsen VI (Hemiptera: Heteroptera). Nederlandse Faunistische Mededelingen 46: 57-86.

AWAd J., VASilițaC., WenZS.,AlKarrat H.,Zimmermann O., ZeBitZC.\& KrogmannL.(2021). New records of German Scelionidae (Hymenoptera: Platygastroidea) from the collection of the State Museum of Natural History Stuttgart. Biodiversity Data Journal 9: e69856. https://doi.org/10.3897/BDJ.9.e69856

AWAN M.S., WILSON L.T. \& HofFMAN M.P. (1990). Comparative biology of three geographic populations of Trissolcus basalis (Hymenoptera: Scelionidae). Environmental Entomology 19 (2): 387-392. https://doi.org/10.1093/ee/19.2.387 
Balusu R., Talamas E.J., Cottrell T., Toews M., Blaauw B., Sial A., Buntin D., Fadamiro H. \& TILLMAN G. (2019). First record of Trissolcus basalis (Hymenoptera: Scelionidae) parasitizing Halyomorpha halys (Hemiptera: Pentatomidae) in the United States. Biodiversity Data Journal 7: 1-9. https://doi.org/10.3897/BDJ.7.e39247

BARClaY M.V.L. (2004). The green vegetable bug Nezara viridula (L., 1758) (Hem.: Pentatomidae) new to Britain. The Entomologist's Record and Journal of Variation 116: 55-58.

BARISElli M., Bugiani R. \& MAistrello L. (2016). Distribution and damage caused by Halyomorpha halys in Italy. EPPO Bulletin 46 (2): 332-334. https://doi.org/10.1111/epp.12289

Bin F., Vinson S.B., StRand M.R., ColazZa S \& Jones W.A. (1993). A source of an egg kairomone for Trissolcus basalis, a parasitoid of Nezara viridula. Physiological Entomology 18: 7-15.

https://doi.org/10.1111/j.1365-3032.1993.tb00443.x

CANTÓN-RAmos J.M. \& CALlejón-FerRe A-J. (2010). Raising Trissolcus basalis for the biological control of Nezara viridula in greenhouses of Almería (Spain). African Journal of Agricultural Research 5 (23): 3207-3212.

Chen H., Lahey Z., Talamas E.J., Valerio A.A., Popovici O.A., Musetti L., Klompen H., Polaszek A., MASNER L., AUSTin A.D. \& JohnSON N.F. (2021). An integrated phylogenetic reassessment of the parasitoid superfamily Platygastroidea (Hymenoptera: Proctotrupomorpha) results in a revised familial classification. Systematic Entomology 4: 1088-1113. https://doi.org/10.1111/syen.12511

Claerebout S., Haye T., Olafsson E., Pannier E. \& Bultot J. (2019). Premières occurrences de Halyomorpha halys (Stål, 1855) pour la Belgique et actualisation de sa répartition en Europe (Hemiptera: Heteroptera: Pentatomidae). Bulletin de la Société royale belge d'Entomologie 154: 205-227.

Colazza S. \& BIN F. (1995). Efficiency of Trissolcus basalis (Hymenoptera: Scelionidae) as an egg parasitoid of Nezara viridula (Heteroptera: Pentatomidae) in central Italy. Environmental Entomology 24: 1703-1707. https://doi.org/10.1093/ee/24.6.1703

de Jong Y., Verbeek M., Michelsen V., de Place Bjørn P., Los, W., Steeman F., Bailly N., Basire C., Chylarecki P., Stloukal E., Hagedorn G., Wetzel F.T., Glöckler F., Kroupa A., Korb G., Hoffmann A., Häuser C., Kohlbecker A., Müller A., Güntsch A., Stoev P. \& Penev L. (2014). Fauna Europaea - all European animal species on the web. Biodiversity Data Journal 2: e4034. https://doi.org/10.3897/BDJ.2.e4034. Available from https://fauna-eu.org [accessed on 20 October 2021].

DETHIER M. \& CHÉROT F. (2014). Alien Heteroptera in Belgium: a threat for our biodiversity or agroforestry? Andrias 20: 51-55.

FOGAIN R. \& GRAFF S. (2011). First records of the invasive pest, Halyomorpha halys (Hemiptera: Pentatomidae), in Ontario and Quebec. Journal of the Entomological Society of Ontario 142: 45-48.

Folmer O., BlACK M., HOEH W., LUTZ R. \& VRIJENHOEK R. (1994). DNA primers for amplification of mitochondrial cytochrome c oxidase subunit I from diverse metazoan invertebrates. Molecular Marine Biology and Biotechnology 3: 294-299.

GBIF Occurrence Download. https://doi.org/10.15468/d1.29xhzu. Available from https://gbif.org [accessed on 20 October 2021].

Grozea I., Virteiu A.M., Stef R., Carabet A., Molnar L., Marcu V. \& Draga D. (2016). The spread of Nezara viridula (Hemiptera: Pentatomidae) species from its first occurrence in Romania. Bulletin of University of Agricultural Sciences and Veterinary Medicine Cluj-Napoca, Horticulture 73 (2): 237. https://doi.org/10.15835/buasvmen-hort:12128 
Haye T., Gariepy T., Hoelmer K., Rossi J-P., Streito J-C., Tassus X. \& DesneuX N. (2015). Range expansion of the invasive brown marmorated stinkbug, Halyomorpha halys: an increasing threat to field, fruit and vegetable crops worldwide. Journal of Pest Science 88: 665-673.

https://doi.org/10.1007/s10340-015-0670-2

Hemala V. \& KMENT P. (2017). First record of Halyomorpha halys and mass occurrence of Nezara viridula in Slovakia (Hemiptera: Heteroptera: Pentatomidae). Plant Protection Science 53: 247-253. https://doi.org/10.17221/166/2016-PPS

HoebeKe E.R. \& CARTER M.E. (2003). Halyomorpha halys (Stål) (Heteroptera: Pentatomidae): a polyphagous plant pest from Asia newly detected in North America. Proceedings of the Entomological Society of Washington 105: 225-237.

HoKkANen H. (1986). Polymorphism, parasites, and the native area of Nezara viridula (Hemiptera: Pentatomidae). Annales Entomologicae Fennicae 52: 28-31.

JoHNSON N.F. (1987). Systematics of New World Trissolcus, a genus of pentatomid egg-parasites (Hymenoptera: Scelionidae): Neotropical species of the flavipes group. Journal of Natural History 21: 285-304. https://doi.org/10.1080/00222938700771021

JONES W.A. (1988). World review of the parasitoids of the southern green stinkbug, Nezara viridula (L.) (Heteroptera: Pentatomidae). Annals of the Entomological Society of America 81: 262-273. https://doi.org/10.1093/aesa/81.2.262

Koch R.L., Pezzini D.T., Michel A.P. \& Hunt T.E. (2017). Identification, biology, impacts and management of stink bugs (Hemiptera: Heteroptera: Pentatomidae) of soybean and corn in the Midwestern United States. Journal of Integrated Pest Management 8 (1): 1-14. https://doi.org/10.1093/jipm/pmx004

LeE D-H., SHORT B.D., JosePH S.V., BERGH J.C. \& LESKEY T.C. (2013). Review of the biology, ecology, and management of Halyomorpha halys (Hemiptera: Pentatomidae) in China, Japan, and the Republic of Korea. Environmental Entomology 42: 627-641. https://doi.org/10.1603/EN13006

Leskey T.C., Hamilton G.C., Nielsen A.L., Polk D.F., Rodriguez-SAOnA C., Bergh J.C., Herbert D.A., Kuhar T.P., Pfeiffer D., Dively G.P., Hooks C.R.R., RaupP M.J., Shrewsbury P.M., Krawczyk G., Shearer P.W., Whalen J., Koplinka L.C., Myers E., InKley D., Hoelmer K.A., LEE D-H. \& WRIGHT S.E. (2012). Pest status of the brown marmorated stink bug, Halyomorpha halys in the USA. Outlooks on Pest Management 23: 218-226. https://doi.org/10.1564/23oct07

Martorana L., Foti M.C., Rondoni G., Conti E., Colazza S. \& Peri E. (2017). An invasive insect herbivore disrupts plant volatile-mediated tritrophic signalling. Journal of Pest Science 90: 1079-1085. https://doi.org/10.1007/s10340-017-0877-5

MATtiacci L., Vinson S.B., Williams H.J., AldRich J.R. \& Bin F. (1993). A long-range attractant kairomone for egg parasitoid Trissolcus basalis, isolated from defensive secretion of its host, Nezara viridula. Journal of Chemical Ecology 19: 1167-1181. https://doi.org/10.1007/BF00987378

MCPHerson J.E. \& MCPHERSON R.M. (2000). Stink Bugs of Economic Importance in America North of Mexico. CRC Press, Boca Raton, Florida.

Musolin D. L. (2012). Surviving winter: diapause syndrome in the southern green stink bug Nezara viridula in the laboratory, in the field, and under climate change conditions. Physiological Entomology 37 (4): 309-322. https://doi.org/10.1111/j.1365-3032.2012.00846.x

PANIZZI A.R. (2000). Suboptimal nutrition and feeding behavior of hemipterans on less preferred plant food sources. Anais da Sociedade Entomológica do Brasil 29: 1-12.

https://doi.org/10.1590/S0301-80592000000100001 
RABITSCH W. (2016). Notizen zur Wanzenfauna (Hemiptera: Heteroptera) von Wien, mit fünf Neufunden für Österreich. Beiträge zur Entomofaunistik 17: 39-54.

Rahat S., GurR G.M., Wratten S.D., Mo J. \& NeEson R. (2005). Effect of plant nectars on adult longevity of the stinkbug parasitoid, Trissolcus basalis. International Journal of Pest Management 51 (4): 321-324. https://doi.org/10.1080/09670870500312778

RÉDEI D. \& TORMA A. (2003). Occurence of the Southern Green Stink Bug, Nezara viridula (Heteroptera: Pentatomidae) in Hungary. Acta Phytopathologica et Entomologica Hungarica 38 (3-4): 365-367. https://doi.org/10.1556/aphyt.38.2003.3-4.17

Rice K.B., Bergh C.J., Bergmann E.J., Biddinger D.J., Dieckhoff C., Dively G., Fraser H., Gariepy T., Hamilton G., Haye T. \& Herbert A. (2014). Biology, ecology, and management of brown marmorated stink bug (Hemiptera: Pentatomidae). Journal of Integrated Pest Management 5 (3): 1-13. https://doi.org/10.1603/IPM14002

Rondoni G., Bertoldi V., Malek R., Foti M.C., Peri E., Maistrello L., Haye T. \& Conti E. (2017). Native egg parasitoids recorded from the invasive Halyomorpha halys successfully exploit volatiles emitted by the plant-herbivore complex. Journal of Pest Science 90: 1087-1095.

https://doi.org/10.1007/s10340-017-0861-0

Schmitz G. (1986). Captures “insolites" d'hétéroptères. Bulletin and Annales de la Société royale belge d'Entomologie 122: 33-38.

Talamas E.J., Buffington M.L. \& Hoelmer K. (2017). Revision of Palearctic Trissolcus Ashmead (Hymenoptera, Scelionidae). In: TALAMAS E.J. \& BufFingTON M.L. (eds) Advances in the systematics of Platygastroidea. Journal of Hymenoptera Research 56: 3-85. https://doi.org/10.3897/jhr.56.10158

Tillman G., Toews M., Blaauw B., Sial A., Cottrell T., Talamas E.J., Buntin D., Joseph S., Balusu R., FADAMIRo H., LAHIRI S. \& PATEL D. (2020). Parasitism and predation of sentinel eggs of the invasive brown marmorated stink bug, Halyomorpha halys (Stål) (Hemiptera: Pentatomidae), in the southeastern US. Biological Control 145: 104247. https://doi.org/10.1016/j.biocontrol.2020.104247

Tortorici F., Talamas E.J., Moraglio S.T., Pansa M.G., Asadi-Farfar M., Tavella L. \& CALECA V. (2019). A morphological, biological and morphological approach reveals four cryptic species of Trissolcus (Hymenoptera, Scelionidae), egg parasitoids of Pentatomidae (Hemiptera). Journal of Hymenoptera Research 73: 153-200. https://doi.org/10.3897/jhr.73.39052

WeRmelinger B., Wyniger D. \& Forster B. (2008). First records of an invasive bug in Europe: Halyomorpha halys Stål (Heteroptera: Pentatomidae), a new pest on woody ornamentals and fruit trees? Mitteilungen der Schweizerischen Entomologischen Gesellschaft 81: 1-8.

WERNER D.J. (2005). Nezara viridula (Linnaeus, 1758) in Köln und in Deutschland (Heteroptera, Pentatomidae). Heteropteron 21: 29-31.

Ziska L.H., Blumenthal D.M., Runion G.B., Hunt E.R. JR. \& Diaz-Soltero H. (2011). Invasive species and climate change: an agronomic perspective. Climate Change 105: 13-42.

https://doi.org/10.1007/s10584-010-9879-5

Manuscript received: 9 August 2021

Manuscript accepted: 18 November 2021

Published on: 26 November 2021

Branch editor: Frederik Hendrickx 